\title{
Öğrenen Organizasyonların Anlaşılmasında ve Başarısında Bir Yöntem Olarak Uygulama Takımları: Bir Şirketler Grubunda Uygulama
}

\author{
Prof. Dr. Mustafa Atilla ARICIOĞLU \\ Necmettin Erbakan Üniversitesi Siyasal Bilgiler Fakültesi İşletme Bölümü, \\ maaricioglu@gmail.com, Orcid ID: 0000-0001-6477-832X
}

\section{Ayşe Berrak HELVACIOĞLU}

Kuveyt Türk BT Test Servisi Necmettin Erbakan Üniversitesi Sosyal Bilimler Enstitüsü

İşletme Yüksek Lisans Öğrencisi

berrak.guldogan@gmail.com, Orcid ID: 0000-0002-5533-4572

\section{$\ddot{O ̈ z}$}

Dinamik bir çevre ve farklılıkların giderek arttığı bir dünyada örgütlerin bu değişime uyum sağlaması önemli bir zorluk olarak tartışılmaktadır. Önerilen ve kullanılan çeşitli yöntem ve araçlar, örgütsel yapıların sürdürülebilirliği açısından önemli bir tartışma konusudur. Peter Senge ile birlikte anılan öğrenen örgütler yaklaşımı da bu bağlamda ele alınmaktadır. Uygulama konusunda Türkiye özelinde karşılığ 1 çok fazla olmayan bu yaklaşımla ilgili olarak, yapılacak olan çalışmalar yaklaşımın anlamını ortaya koyacaktır. Bu bağlamda yürütülmüş olan Araştırmanın amacı, Öğrenen Organizasyon Uygulama Takımları'nın (“ÖOUT”) kurumların, organizasyonel öğrenme seviyelerini ölçmelerini ve ölçüm sonuçlarını değerlendirmelerini sağlamak, ÖOUT'nın kurumların öğrenme kültüründeki rolünü tespit etmeye yardımcı olacak örnek bir çalışma sunmaktır. Çalışmanın yürütülmesinde ihtiyaç duyulan veriler bir holding bünyesinde faklı faaliyet alanlarında çalışan ve 3'ünün bünyesinde ÖOUT'1 bulunan 7 profesyonel şirketten sağlanmıştır. Çalışma ile grup şirketlerinin ÖOUT'na dair süreçleri ve organizasyonel öğrenme seviyeleri incelenirken, elde edilen sonuçlarla holdinge bağlı şirketlerin, ÖOUT'na neden ihtiyaç duyduğu, bunları nasıl oluşturabilecekleri ve nasıl işletecekleri ölçülerek, kapsamlı bir vaka ile açıklanmıştır.

Anahtar Kelimeler: Öğrenen organizasyonlar, uygulama takımları,

JEL Sınıflandırması: D83, L21, L22, M53, M55 


\title{
Practice Teams as a Method for Understanding and Success of Learning Organizations: Application in a Group of Companies
}

\begin{abstract}
In a dynamic environment and a world where differences are increasing, the adaptation of organizations to this change is discussed as an important challenge. Various methods and tools proposed and used are an important discussion topic for the sustainability of organizational structures. The learning organizations approach mentioned with Peter Senge is also considered in this context. Turkey in particular as regards implementation of the provisions of this approach is not much work to be done will reveal the meaning of the approach. The aim of the research carried out in this context is to enable the Learning Organization Implementation Teams ("OOUT") to measure the organizational learning levels of institutions and to evaluate the measurement results, and to present an exemplary study to help determine the role of OOUT in the learning culture of institutions. The data needed in the execution of the study was obtained from 7 professional companies, 3 of which work in different fields of activity within a holding, and 3 of them have OOUT. With the study, the processes and organizational learning levels of group companies regarding OOUT are examined, and the results of the holding company are explained with a comprehensive case by measuring why the companies affiliated to the holding need OOUT, how they can create and operate them.
\end{abstract}

Keywords: Learning organizations, practice teams,

JEL Classification: D83, L21, L22, M53, M55

\section{Giriş}

Örgüt-çevre ilişkisi bağlamında yapılan tartışmalar, eski olduğu kadar içerdiği öneriler ve ortaya konulan önermeler bağlamında ele alındığında oldukça zengin bir içeriğe sahiptir. Özellikle işletme örgütlerinin sürdürülebilirliği bağlamında tartışmalara bakıldığında çevrenin, teknolojinin ve kültürün örgütün varlığı açısından önemli unsurlar olduğu bilinmektedir.

$\mathrm{Bu}$ bağlamda hem örgüt teorisi hem örgütsel davranış hem de yönetim yaklaşımları açısından örgütün çevre ile ilişkisinde öğrendikleri kadar öğrendiklerini uygulayıp uygulayamadıkları önemli bir sorun olarak ele alınmaktadır. Örgütlerin bilgiyi yaratması, çevrenin bilgisini kullanması ve yeni aynı zamanda artan uzman bilgisini örgüt ve yönetimin kullanabileceği bir hale getirmesi (Garvin, 1993:80-82) bu sorunun çözümü olarak sunulur. Sürecin içerisindeki ilişkilerin özellikle sistem yaklaşımı üzerinden ele alınması ve örgütlerin bu öğrenmeyi nasıl gerçekleştireceği ise Senge'nin (1993: 11) tanımı ile karşılık bulmaktadır: "Bu organizasyonlarda kişiler; gerçekten istedikleri sonuçları yaratmak için kapasitelerini durmadan genişletirler, buralarda yeni ve coşkun düşünme tarzları beslenir, kolektif özlemlere gem vurulmaz ve insanlar nasıl birlikte öğrenileceğini, sürekli olarak öğrenirler”. Öğrenme, çok yönlü/iki 
yönlü bir süreçtir ve iç-dış çevrenin hatalarının giderilmesine ilişkin alınan önlemler bağlamında da öğrenmenin gelişimin sağlar (Schein, 1996:11-16). Nitekim Senge, Öğrenen Organizasyonları "geleceğini yaratma kapasitesini durmadan genişleten organizasyonlar" olarak tanımlarken, bunun "hayat boyu sürecek bir yolculuk" olarak düşünmek gerektiğini vurgular. Ona göre; "Öğrenen Organizasyon, insanların kendi gerçekliklerini nasıl yaratacaklarını ve nasıl değiştirebileceklerini keşfettikleri bir yerdir" (Senge, 1990:17- 33). Mills ve Freisen bu keşfin, kaliteyi geliştiren, müşteri/tedarikçi ilişkilerini arttıran, ya da daha etkili iş stratejileri kullanarak içsel yenilenmeyi ve karlılığı kalıcı hale getiren oluşumlarla mümkün olduğunu belirtir (Bontis, 2002: 439). Bu bağlamda süreç, "yeni bilgi ve kavrayışları yansıtmak için değiştirme becerisine sahip olmayı" (Garvin, 1993: 4), "bireylerin gelişmesine olanak sağlayan bir ortam yaratmayı" (Dikmen, 1999: 62) ve böylelikle "arzu ettikleri ortak geleceğe ulaşmayı" (Çalkavur,2006: 59) kapsar.

Ancak sürecin uygulama karşılığı ve uygulama takımları üzerinden nasıl yürütüldüğü Türkiye'deki şirketler açısından önemli örneklere ihtiyaç bulunmaktadır. Uygulamaya ilişkin özellikle uygulama takımlarının kurulması ve kullanılması ile bunlar aracılığı ile ilgili edinilen başarılar farklı örnekler üzerinden anlatılabilir (Çalkavur, 2006:23-27).

Öğrenen organizasyon yaklaşımının uygulama takımları üzerinden ele alındığı bu vaka çalışmasında da, uygulama kısmında da ayrıca belirtildiği üzere:

- Uygulama yapılan grup şirketleri bütününün “öğrenme ortamı” içerisinde gruplar arasında farklılıkların bulunup, bulunmadığı,

- Çalışılma yapılan örgütlerde somut öğrenme süreçleri ve uygulamaları içerisinde gruplar arasında farklılıklar varsa bunların neden kaynaklandığı,

- Öğrenmeyi sağlamlaştıran liderlik içerisinde gruplar arasında farklılıkların gerekçelerinin neler olduğu araştırılacaktır.

Bu bağlamda yürütülen çalışmanın amacı da:

- Öğrenen Organizasyon (“ÖO”) Uygulama Takımları’nın kavramsal ve kuramsal özelliklerini,

- ÖO Uygulama Takımları'na zaman ve kaynak ayıran veya ayırmayı planlayan kurumların, organizasyonel öğrenme seviyelerini ölçmelerini ve ölçüm sonuçlarını değerlendirmelerini,

- OOO Uygulama Takımları'nın kurumların öğrenme kültüründeki rolünü etkin kılacak yönlerini tespit etmeye yardımcı olacak, örnek bir çalışma ortaya koymaktır.

Böylelikle, ÖO kültürünü kurumları bünyesinde nasıl uygulamaya başlayacağını ve geliştireceğini bilmeyen ancak ÖO felsefesine değer veren kurum ve işletmelere uygulama, ölçme ve değerlendirmede yol gösterecektir. ÖO Uygulama Takımları sistematiğinin Konya'da ilk defa bir şirketler grubunda uygulanması ve Anadolu'daki 
Practice Teams as a Method for Understanding and Success of Learning Organizations: Application in a Group of Companies

diğer işletmelere örnek teşkil edecek bir çalışma yapılmış olması araştırılacak konunun seçiminde etkili olmuştur.

\section{Kavramsal Çerçeve}

Öğrenen organizasyonlar ve uygulama takımları ile ilgili kavramsal çerçevenin yanı sıra literatür çalışması ele alınmıştır.

\section{1. Öğrenen Organizasyon Kavramı}

Öğrenen Organizasyon (“ÖO”) kavramının literatürdeki karşılığı incelendiğinde, özellikle bu kavramın öneminin ve bileşenlerinin çokça tartışıldığı, kavramın gelişiminin uygulama sonuçları ile doğrudan bağlantılı olduğu görülmektedir. Bu alanla ilgili yapılan çalışmalar ve bu bağlamda öğrenen organizasyonların anlamı ile kavramsal seyri aşağıdaki tabloda ele alınmaya çalışılmıştır:

\begin{tabular}{|c|c|}
\hline YAZAR; YAYIN; YIL; ÜLKE; SEKTÖR & ARAŞTIRMA ÍÇERÍĞİ \\
\hline $\begin{array}{l}\text { Chris Argyris; Organisational Learning And } \\
\text { Management Information Systems; } \\
\text { 1977; Yönetim Bilişim Sistemleri }\end{array}$ & $\begin{array}{l}\text { Yönetim bilişim sistemlerinin uygulanmasında } \\
\text { yaşanan krizlerin etrafında dönen tartışmaları ÖO } \\
\text { teorisinin ışığında yeniden ele almıştır. }\end{array}$ \\
\hline $\begin{array}{l}\text { Allan Williams; Integrating Individual and } \\
\text { Organisational Learning: A Model and Case Study; } \\
\text { 1980; İngiltere; Finans }\end{array}$ & $\begin{array}{l}\text { Bir finans kuruluşunun insan kaynakları yönetimini } \\
\text { geliştirmek amacıyla, bir işletme okulu ile ortak } \\
\text { çalışmasını anlatır. }\end{array}$ \\
\hline $\begin{array}{l}\text { Graham Orange; The Facilitation of Cross } \\
\text { Organisational Learning and Knowledge } \\
\text { Management to Foster Partnering within the UK } \\
\text { Construction Industry; 1999; İngiltere; İnşaat }\end{array}$ & $\begin{array}{l}\text { Birleşik Krallık inşaat sektörü içinde ortaklıkları } \\
\text { teşvik etmede organizasyonlar arası öğrenme ve bilgi } \\
\text { yönetiminin tesisinin önemini açılar. }\end{array}$ \\
\hline $\begin{array}{l}\text { Eugene Sadler-Smith; Organisational Learning in } \\
\text { Smaller Firms: An Emprical Perspective; } 1999\end{array}$ & $\begin{array}{l}\text { Küçük ve orta büyüklükteki işletmelerde ÖO } \\
\text { uygulamalarını konu edinir. }\end{array}$ \\
\hline $\begin{array}{l}\text { Graham Orange; COLA: A Cross Organisational } \\
\text { Learning Approach within UK Industry;2000; } \\
\text { İngiltere; Sanayi }\end{array}$ & $\begin{array}{l}\text { Birleşik Krallık sanayisindeki organizasyonlar arası } \\
\text { ögrrenme yaklaşımını inceler. }\end{array}$ \\
\hline $\begin{array}{l}\text { Carl Rhodes; Playing with words: Multiple } \\
\text { Representations of Organisational Learning Stories; } \\
1997\end{array}$ & $\begin{array}{l}\text { Farklı seviyelerde çalışan } 3 \text { bireyin ÖO hikâyelerini } \\
\text { anlatan makalesinde, sözlü mülakatlarla edinilen } \\
\text { bilgiler otobiyografik biçimde kendi ifadeleri ile } \\
\text { yazar tarafından yorumlanıp hikâyeleştilerek sunulur. } \\
\text { Araştırma ÖO Uygulama Takımları benzeri bir } \\
\text { yapılanma içinde rol alan üç ayrı bireyin } \\
\text { tecrübelerinden bahseder. }\end{array}$ \\
\hline $\begin{array}{l}\text { Karina Aase; Handbooks as a tool for organizational } \\
\text { learning: a case study; 1998; Norveç; Kıyı Petrol } \\
\text { Endüstrisi }\end{array}$ & $\begin{array}{l}\text { Büyük işletmelerde öğrenmeyi etkileyen hususları } \\
\text { inceleyerek bilgi ve Örgütsel Öğrenmenin } \\
\text { gerçekleşebilmesi için tecrübenin transferinde } \\
\text { dokümantasyon ağırlıklı süreçler yerine özel amaçlı } \\
\text { hazırlanmış el kitaplarını önerir. Pratikteki örneği } \\
\text { Kıyı Petrol Endüstrisinde kullanılması için } \\
\text { hazırlanan bir el kitabı ile verir. }\end{array}$ \\
\hline
\end{tabular}


Öğrenen Organizasyonların Anlaşılmasında ve Başarısında

Bir Yöntem Olarak Uygulama Takımları: Bir Şirketler Grubunda Uygulama

\begin{tabular}{|c|c|}
\hline YAZAR; YAYIN; YIL; ÜLKE; SEKTÖR & ARAŞTIRMA İÇERİĞİ \\
\hline Lyle Yorks; Action Learning; 1999; Finas & $\begin{array}{l}\text { Eylem Halinde Öğrenmeyi, problemleri çözerken ya } \\
\text { da projeleri gerçekleştirirken yapılan işin kişilerin } \\
\text { öğrenmesine ve gelişim sağlamalarına katkıda } \\
\text { bulunması yaklaşımı olarak tanımlar. Kişilerin ve } \\
\text { organizasyonların kendileri için uygun olan öğrenme } \\
\text { yöntemini seçmesini önerir. }\end{array}$ \\
\hline $\begin{array}{l}\text { Edward E. Gordon } \\
\text { The Quality Journey Becomes a Short Trip; 2000; } \\
\text { ABD }\end{array}$ & $\begin{array}{l}\text { Amerikan şirketlerinin ÖO oluşturmada ve } \\
\text { sürdürmede problem yaşamalarındaki temel sebebin; } \\
\text { üst yönetimin ÖO’a çok inanmaması, Amerikan iş } \\
\text { kültüründe eğitim çabalarının yarı gönüllü } \\
\text { yürütülmesi ve temel eğitim alırken çalışanlarda } \\
\text { oluşan öğrenmeye karşı direnç olarak görür. Baskın } \\
\text { bir iş kültürüne sahip firmaların ÖO kültürünü } \\
\text { benimsemeden yeni bir yönetim anlayışı } \\
\text { geliştiremeyeceğinden bahseder. }\end{array}$ \\
\hline $\begin{array}{l}\text { Edward E. Gordon; A Kick in the Butt; } \\
\text { 2000; ABD-Hindistan; Üretim-Kobi }\end{array}$ & $\begin{array}{l}\text { Şirket Üniversitelerinin, ÖO felsefesini idrak ederek } \\
\text { departmanları ve şirketleri ÖO'lara dönüştürmek gibi } \\
\text { ortak bir görevleri olduğunu bildirir. Bu konseptin } \\
\text { gerçek hayata nasıl indirgeneceği konusunda } \\
\text { kurumların yaşadıkları problemlerin aşılmasında } \\
\text { Calvert, Mobley ve Marshall'ın ÖO'ların pratiğe } \\
\text { dökülebilmesi için hazırladığı şablonların } \\
\text { kullanılabileceğini açıklar ve Wabash National } \\
\text { firmasının bunu nasıl sistematik biçimde hayata } \\
\text { geçirdiğini anlatır. }\end{array}$ \\
\hline $\begin{array}{l}\text { Lauri W. Pant; } \\
\text { The Growing Role of Informal Controls: Does } \\
\text { Organization Learning Empower or Subjugate } \\
\text { Workers?; 2001; ABD }\end{array}$ & $\begin{array}{l}\text { Kurumlarda çalışanların bilgisinin artmasıyla } \\
\text { şeffaflığın artacağını ve çalışanların şirketin } \\
\text { kazanımlarından daha fazla pay alacağını söyler. }\end{array}$ \\
\hline $\begin{array}{l}\text { Meinolf Dierkes, Berthoin Antal Ariane, John Child, } \\
\text { Ikujiro Nonaka; } \\
\text { Handbook of Organizational Learning and } \\
\text { Knowledge; 2002; Japonya, ABD, Avrupa }\end{array}$ & $\begin{array}{l}\text { Çok farklı kültür ve eğitim altyapısından yetişmiş } \\
\text { akademisyenlerin Örgütsel Öğrenme üzerine detaylı } \\
\text { görüşlerini sunarken Amerikan ve Avrupalı } \\
\text { gelenekten sıyrılarak Asya ve Orta Doğunun } \\
\text { deneyimlerine de değinir. Örnek vaka analizlerine } \\
\text { yer verir. }\end{array}$ \\
\hline $\begin{array}{l}\text { İlhami Yücel; } \\
\text { Öğrenen Örgütler ve Örgüt Kültürü -Bir Uygulama- ; } \\
\text { 2003; Türkiye }\end{array}$ & $\begin{array}{l}20 \text { ve daha fazla çalışanı olan KOBİ ler üzerinde } \\
\text { çalışılmış, Örgütlerin ÖO kültürüne uygunluğunu } \\
\text { sorgulayarak yol göstermiştir. }\end{array}$ \\
\hline $\begin{array}{l}\text { Anders Örtenblad;A Typology of the Idea of } \\
\text { Learning Organization; 2004; İsveç }\end{array}$ & $\begin{array}{l}\text { ÖO’ ları tipolojik açıdan incelerken bu kavramın } \\
\text { farklı anlamlandırılmasına neden olan farklı bakış } \\
\text { açılarına yer verir. }\end{array}$ \\
\hline $\begin{array}{l}\text { Ron Moore; Training; 2004; ABD; } \\
\text { Otomotiv-Yedek Parça }\end{array}$ & $\begin{array}{l}\text { Beta International firmasında kurumsal hedeflere } \\
\text { ulaşmaya yardımcı olmak için başlatılan stratejik } \\
\text { öğrenme planını anlatır. Senge'nin ÖO kültürüne } \\
\text { dayandırdığı bu stratejik öğrenme sürecini } 12 \text { adımda } \\
\text { açıklar ve yöneticilerin sürece katkısını vurgular. }\end{array}$ \\
\hline $\begin{array}{l}\text { Arthur M. Langer; } \\
\text { IT and Organizational Learning: Managing Change } \\
\text { through Technology and Education; 2005; ABD; } \\
\text { Bilişim }\end{array}$ & $\begin{array}{l}\text { Mevcut Örgütsel Öğrenme teorilerinin bazılarını ve } \\
\text { bunları kullanan şirketlerin yaşadığı sorunları inceler. } \\
\text { Bilişim şirketlerinde ÖO’ları geliştirmenin işletme } \\
\text { sahiplerinin ve yöneticilerin birçok konuyu } \\
\text { anlamalarına ve sorunlarla başa çıkmalarına yardımcı } \\
\text { olacağını savunur. }\end{array}$ \\
\hline
\end{tabular}



and Success of Learning Organizations: Application in a Group of Companies

\begin{tabular}{|c|c|}
\hline YAZAR; YAYIN; YIL; ÜLKE; SEKTÖR & ARAŞTIRMA İÇERİĞİ \\
\hline $\begin{array}{l}\text { James Henri; Marlene Asselin } \\
\text { The Information Literate School Community 2; } \\
\text { 2005; Avustralya-İngiltere; Eğitim }\end{array}$ & $\begin{array}{l}\text { Okulların birer ÖO’a dönüşmesi gerektiğini ve nasıl } \\
\text { olacağını anlatır. Senge'nin disiplinlerini fazla soyut } \\
\text { bulur ve ÖO'lar için alternatif ilkeler sunar. }\end{array}$ \\
\hline $\begin{array}{l}\text { Peter E.D. Love, Jimmy Huang, David J. Edwards, } \\
\text { Zahir Irani; Building a learning organization in a } \\
\text { project-based environment; 2005; } \\
\text { Avustralya-İngiltere; İnşaat }\end{array}$ & $\begin{array}{l}\text { İnşaat organizasyonlarının maliyet ve zaman baskısı } \\
\text { altındaki proje bazlı iş ortamını dikkate alarak inşaat } \\
\text { şirketlerinde “Öğrenen İnşaat Organizasyonu’nun } \\
\text { nasıl olabileceğine değinir. Şirketi dönüştürmede } \\
\text { Toplam Kalite Yönetimi ile ÖO kültürünü birbirinin } \\
\text { tamamlayıcısı olarak görür ve ancak o zaman proje } \\
\text { bazlı hatalardan çıkarılan derslerin şirket hafızasına } \\
\text { yerleştirilebileceğini açıklar. }\end{array}$ \\
\hline $\begin{array}{l}\text { Dale W. Lick; A new perspective on organizational } \\
\text { learning: Creating learning teams; 2006; ABD; } \\
\text { Eğitim }\end{array}$ & $\begin{array}{l}\text { ÖO konseptini Öğrenen Takımlar oluşturarak } \\
\text { yerleştirmeye çalışan eğitim örgütlerinden bahseder. } \\
\text { Bu takımların oluşmasında esas maksadın takımların } \\
\text { hedefledikleri sonuçlara ulaşmasını sağlamaktan } \\
\text { ziyade öğrenen topluluklar oluşturarak değişimi } \\
\text { yönetme kabiliyetini kazandırmak olduğunu açıklar. }\end{array}$ \\
\hline $\begin{array}{l}\text { Linda Holbeche; Understanding Change; } \\
\text { 2006; İngiltere }\end{array}$ & $\begin{array}{l}\text { Yüksek performanslı organizasyonların nasıl } \\
\text { oluştuğuna dair teorileri sunar ve bunların zaman } \\
\text { içindeki dönüşümünü anlatır. Yüksek performanslı } \\
\text { organizasyonu tanımlarken verilen teorileri hayata } \\
\text { geçirmede ve değişimin önündeki direnci kırmada } \\
\text { kilit roldeki liderlerin uygulamalardan bahseder. }\end{array}$ \\
\hline $\begin{array}{l}\text { Evrim Çalkavur; Öğrenen Organizasyon Yolculuğu } \\
\text { Bir Başarı Öyküsü; 2006; Türkiye }\end{array}$ & $\begin{array}{l}\text { ÖO’u bitmeyen bir yolculuk olarak ele alır. ÖO } \\
\text { disiplinlerini somut projeler ile hayata geçiren } \\
\text { takımların koçluğunu yaptığı dönemlerdeki yöntem } \\
\text { ve kazanımları anlatır. }\end{array}$ \\
\hline $\begin{array}{l}\text { Tracy Taylor, Alison Doherty, Peter McGraw; } \\
\text { Training and development in sport organizations; } \\
\text { 2008; Avustralya-İngiltere; Spor }\end{array}$ & $\begin{array}{l}\text { Kuruluşların Örgütsel Öğrenme’yi optimize ederken } \\
\text { sürekli öğrenmeye firsatlar yarattığından bahseder. } \\
\text { Senge'nin ÖO’u, Nonaka \& Takeuchi’nin Bilgi } \\
\text { Oluşturma, Drucker'ın Bilgi Yönetimi yapılarını } \\
\text { inceler. }\end{array}$ \\
\hline $\begin{array}{l}\text { Gopesh Anand, Peter T. Ward, Mohan V. Tatikonda, } \\
\text { David A. Schilling; } \\
\text { Dynamic capabilities through continuous } \\
\text { improvement infrastructure; 2009; ABD; } \\
\text { Sağlık, Hizmet, Kimya, Tıbbi Cihaz, Yüksek } \\
\text { Teknoloji }\end{array}$ & $\begin{array}{l}\text { Sağlık, Hizmet, Kimya, Tıbbi Cihaz ve Yüksek } \\
\text { Teknoloji sektörlerinden birer şirket üzerinde yapılan } \\
\text { araştırmada Sürekli İyileştirme'nin kapsamlı bir } \\
\text { organizasyon ortamında oluşabileceğini ve bunu } \\
\text { sağlamada ÖO öğretisinin olması gerektiğini } \\
\text { savunur. }\end{array}$ \\
\hline $\begin{array}{l}\text { Linda Holbeche; Creating a Learning Culture; 2009; } \\
\text { İngiltere; Belediye, Perakende, Bilişim, Ulaşım }\end{array}$ & $\begin{array}{l}\text { Örgütsel Öğrenme’nin önündeki engellerden } \\
\text { bahseder. UK Local Authority, Sainsbury’s, Sun } \\
\text { Microsystems, NATS (National Air Traffic Services) } \\
\text { gibi kuruluşların ÖO olma yolundaki yöntemlerini } \\
\text { verir. }\end{array}$ \\
\hline $\begin{array}{l}\text { Wolf Heydebrand; Accounting for great } \\
\text { expectations: Lessons from the new media surge for } \\
\text { critical management theory; 2009; ABD; Bilişim }\end{array}$ & $\begin{array}{l}\text { 1995-2001 yılları arasında Silikon Vadisi'ndeki } \\
\text { organizasyonel değişimleri anlatır. Senge'nin ÖO } \\
\text { yaklaşımının bu organizasyonlarda yer edindiğini } \\
\text { anlatır. }\end{array}$ \\
\hline
\end{tabular}


Öğrenen Organizasyonların Anlaşılmasında ve Başarısında Bir Yöntem Olarak Uygulama Takımları: Bir Șirketler Grubunda Uygulama

\begin{tabular}{|c|c|}
\hline YAZAR; YAYIN; YIL; ÜLKE; SEKTÖR & ARAŞTIRMA İÇERİĞİ \\
\hline $\begin{array}{l}\text { Kristin J. Henrich, Ramirose Attebury; } \\
\text { Communities of Practice at an Academic Library: A } \\
\text { New Approach to Mentoring at the University of } \\
\text { Idaho; 2010; ABD; } \\
\text { Eğitim }\end{array}$ & $\begin{array}{l}\text { Idaho Üniversitesi'nde ÖO’u pratiğe döken } \\
\text { topluluklarının nasıl oluştuğu ve dönüştügünü ortaya } \\
\text { koyan bir çalışmadır. }\end{array}$ \\
\hline $\begin{array}{l}\text { Paul Jackson; From function to use; } 2010 \\
\text { ABD, İngiltere }\end{array}$ & $\begin{array}{l}\text { Bireysel-Örgütsel Öğrenme ve Organizasyon } \\
\text { Hafızası hakkında bilgi verir. Organizasyonel Hafıza } \\
\text { ve Örgütsel Öğrenme'nin prosedürlerini şemalar } \\
\text { halinde açıklar. }\end{array}$ \\
\hline $\begin{array}{l}\text { Maureen Fitzgerald Murray, Jeanne-Marie Havener, } \\
\text { Patricia S. Davis, Connie Jastremski, Martha L. } \\
\text { Twichell; } \\
\text { The Rural Pipeline: Building a Strong Nursing } \\
\text { Workforce Through Academic and Service } \\
\text { Partnerships; 2011; ABD; } \\
\text { Sağlık }\end{array}$ & $\begin{array}{l}\text { Basset Sağlık Merkezi’nin Eğitim altyapısını ÖO } \\
\text { kültürüne adapte ederek yeniden düzenlediği ve } \\
\text { başarının şartları olarak gördüğ̈ü prensipleri ÖO } \\
\text { disiplinleri üzerine bina ettiği anlatılır. Güçlü bir } \\
\text { hemşirelik işgücünün oluşturulmasında bu kültürün } \\
\text { 2005-2009 yılları arasındaki etkisi verilerle ortaya } \\
\text { konur. }\end{array}$ \\
\hline $\begin{array}{l}\text { Anders Örtenblad; Handbook of Research on the } \\
\text { Learning Organization: Adaptation and Context; } \\
\text { 2013; Çin; Güvenlik; Hizmet }\end{array}$ & $\begin{array}{l}\text { ÖOların her organizasyonun kabul edebileceği } \\
\text { düzeyde olduğunu ele alır çok farklı sektörlerde } \\
\text { örnekler kullanarak açıklar. }\end{array}$ \\
\hline $\begin{array}{l}\text { Joan Giesecke, Charlene Maxey-Harris; } \\
\text { Cultural competencies in authentic leadership; 2013; } \\
\text { ABD; Eğitim }\end{array}$ & $\begin{array}{l}\text { ÖO modelinin 1990’ların sonunda ilk uygulandığı } \\
\text { kütüphanelerden birini inceler. }\end{array}$ \\
\hline $\begin{array}{l}\text { Nurazree Mahmud, Mohd Faiz Hilmi; } \\
\text { TQM and Malaysian SMEs Performance: The } \\
\text { Mediating Roles of Organization Learning; 2014; } \\
\text { Malezya; } \\
\text { Üretim-Kobi }\end{array}$ & $\begin{array}{l}\text { Toplam Kalite Yönetimi ile KOBİler arasındaki } \\
\text { ilişkiyi araştırırken Örgütsel Öğrenme } \\
\text { uygulamalarının bağdaştırıcı rolünden bahseder. }\end{array}$ \\
\hline $\begin{array}{l}\text { Fadime Çınar, Erol Eren; Organizational Learning } \\
\text { Capacity Impact on Sustainable Innovation: The } \\
\text { Case of Public Hospitals; 2015; Türkiye; Sağlık }\end{array}$ & $\begin{array}{l}17 \text { hastanede Örgütsel Öğrenme Kapasitesi üzerinde } \\
\text { yapplan araştırmanın sonuçlarından, Örgütsel } \\
\text { Öğrenme ile Yenilenme arasındaki ilişki tespit } \\
\text { edilmeye çalışılmıştır. }\end{array}$ \\
\hline $\begin{array}{l}\text { Silvia Gherardi; Learning: Organizational; 2015; } \\
\text { İtalya }\end{array}$ & $\begin{array}{l}\text { Bilmeyi ve öğrenmeyi ön plana çıkaran } \\
\text { uygulamaların başarılı bir ÖO teşkil edebileceğini } \\
\text { işler. }\end{array}$ \\
\hline $\begin{array}{l}\text { Zeynep Kabadayı Kuşcu, Müjdelen Yener, Gülruh } \\
\text { Gürbüz; Learning Organization and its Cultural } \\
\text { Manifestations: Evidence from a Global White } \\
\text { Goods Manufacturer; 2015; } \\
\text { Türkiye; Beyaz Eşya }\end{array}$ & $\begin{array}{l}\text { Beyaz Eşya sektöründeki lider bir şirketin ana } \\
\text { rekabet gücünü incelerken kritik olan } \\
\text { karakteristiğinin ÖO olduğunu vurgular. ÖO } \\
\text { olmanın kompleks teorisini açılamak için örnek } \\
\text { vaka tekniği ile Senge'nin beş disiplininin şirket } \\
\text { altyapısında nasıl yer edindiğini analiz eder. }\end{array}$ \\
\hline $\begin{array}{l}\text { Nuran Kaya; Öğrenen Organizasyon, Yenilik Ve } \\
\text { Değişim Mühendisliği Uygulamalarının Firma } \\
\text { Performansı Üzerindeki Etkileri; 2015; Türkiye }\end{array}$ & $\begin{array}{l}\text { ÖO uygulamalarına vurgu yapılırken bunların } \\
\text { uygulanış prensipleri yerine çeşitli sektörlerdeki } \\
\text { firmaların performansına etkileri bulunmaya } \\
\text { çalışılmıştır. }\end{array}$ \\
\hline $\begin{array}{l}\text { Evrim Çalkavur, Yavuz Durmuş; Alan Derin Bir } \\
\text { Nefes; 2015;Türkiye; Eğitim, Tekstil, İnsan } \\
\text { Kaynakları, Çimento }\end{array}$ & $\begin{array}{l}\text { ÖO Uygulamalarına dair teorik gerçekler farklı } \\
\text { sektörlerden somut örnekler üzerinde incelenmiştir. }\end{array}$ \\
\hline $\begin{array}{l}\text { Tie Li, Yi Peng, Yong Shi, Gang Kou } \\
\text { Study on Multi-agent Based Simulation of Team } \\
\text { Machine Learning; 2016;ABD, } \\
\text { Bilişim }\end{array}$ & $\begin{array}{l}\text { İnsan topluluklarının kullandığı organizasyon } \\
\text { teorileri temel alınarak makine ögrenimi alanında } \\
\text { makineler arasında da takım halinde öğrenme } \\
\text { koordinasyonundan bahseder. }\end{array}$ \\
\hline
\end{tabular}



and Success of Learning Organizations: Application in a Group of Companies

\begin{tabular}{|l|l|}
\hline YAZAR; YAYIN; YIL; ÜLKE; SEKTÖR & ARAŞTIRMA İÇERIĞĠ \\
\hline $\begin{array}{l}\text { Ho Wook Shin, Joseph C. Picken, Gregory G. Dess; } \\
\text { Revisiting the learning organization: How to create } \\
\text { it; 2017; ABD }\end{array}$ & $\begin{array}{l}\text { Bir örgütün tüm seviyelerinde değişimin ve gelişim } \\
\text { bariyerlerinin üstesinden gelmenin zor olduğunu } \\
\text { ancak ÖO'larnn bunu merkeze alarak yapılanması } \\
\text { gerektiğini bildirir. }\end{array}$ \\
\hline $\begin{array}{l}\text { Masanori Koizumi; Incompatibility of Business } \\
\text { Management Theories in Library Management; } \\
\text { 2017; ABD; Eğitim }\end{array}$ & $\begin{array}{l}\text { Yönetim teorilerinin uygulama örneklerini inceler. } \\
\text { Bazı kavramlarının kütüphanecilikte karşıllğı } \\
\text { yokmuş gibi görünmesine rağmen ÖO'ları } \\
\text { kütüphaneler için uygulanabilir kategoride tutar. }\end{array}$ \\
\hline
\end{tabular}

Literatürün izlediği akış incelendiğinde öğrenen organizasyon kavramının ve bileşenlerinin çokça tartışıldığı 1990'larda araştırmacılar, aslında öğrenen organizasyonları 4 kavram üzerinden tartışmışlardır (Örtenblad, 2002):

- Eski Organizasyonel Öğrenme: Örgüt hafizasını oluşturan bilgi birikimi bireylerin öğrenmesinden oluşur.

- İște Öğrenme: Çalışanların dış kurslar/eğitimler yerine işte öğrenmeleri.

- Öğrenme İklimi: Bireylerin öğrenmesini kolaylaştıran ortam şartları.

- Öğrenme Yapısı: Bireyler ve takımlar arasında birbirlerinin fonksiyonlarını yerine getirebilecek dağıtılmış, merkeziyetçi olmayan yapı.

Söz konusu araştırmacıların bu kavramı açıklamada, birincil (Esas Önem Verilen) ve ikincil (Az Önem Verilen) olarak ele aldığı anlayışlar Tablo 1'de özetlenmiştir.

\section{Tablo 1. Öğrenen Organizasyon fikrinin araştırmacılardaki anlayış biçimleri}

\begin{tabular}{|l|l|l|l|l|}
\hline \multicolumn{1}{|c|}{ 1990'ların araştırmaciları } & $\begin{array}{c}\text { Eski } \\
\text { Organizasyo } \\
\text { nel Öğrenme }\end{array}$ & $\begin{array}{c}\text { İște } \\
\text { Öğrenme }\end{array}$ & $\begin{array}{c}\text { Öğgrenme } \\
\text { Íklimi }\end{array}$ & $\begin{array}{c}\text { Öğrenme } \\
\text { Yapısı }\end{array}$ \\
\hline Garratt, 1990 & & & & \\
\hline Senge, 1990 & & & & \\
\hline Lessem, 1991 & & & \\
\hline Pedler, Burgoyne \& Boydell, 1991 & & & & \\
\hline Jones \& Hendry, 1992 & & & \\
\hline McGil, Slocum \& Lei, 1992 & & & & \\
\hline Garvin, 1993 & & & & \\
\hline Watkins \& Marsick, 1993 & & & & \\
\hline Jones \& Hendry 1994 & & & & \\
\hline Marquardt \& Reynolds, 1994 & & & & \\
\hline West, 1994 & & & \\
\hline Pedler \& Aspinwall, 1998 & & & \\
\hline
\end{tabular}

\begin{tabular}{|l|l|}
\hline Birincil (Esas Önem Verilen) & \\
\hline İkincil (Az Önem Verilen) & \\
\hline
\end{tabular}

Kaynak: (Örtenblad, 2002) 

Bir Sirketler Grubunda Uygulama

Yukarıdaki tablodan da anlaşılacağı üzere ÖO kavramının fikri kökeni "Organizasyonel Öğrenme" düşüncesinden ileri gelmekle beraber, Öğrenen Organizasyon denildiğinde ağırlıklı olarak "Öğrenmeyi Destekleyici Ortam" içerisinde oluşturulan "Somut Öğrenme Süreçleri" akla geldiği ve bu süreçlerin reel "İ̧̧ Uygulamaları" ile pekiştirildiği bir anlayışın ortaya çıktığı görülmektedir.

Bununla birlikte sürecin ve kavramın anlamı üzerinden bir değerlendirme yapıldığında ise durum şu şekilde özetlenebilir:

1960'lar
Öğrenen Organizasyon Konsepti

1990'lar

Öğrenen Organizasyon İhtiyacı ve Önemi

2000'ler

Öğrenen Organizasyon Uygulamaları

2010 ve sonrası

Öğrenen Organizasyon Uygulama

Takımları
Kurumların öğrenmesine ilişkin ilk kavramsal yaklaşımlar ve genel teoriler, Chris Argyris (Argyris, 1977), Richard Michael Cyert, James Gardner March ve Edith Penrose (Pitelis, 2007) gibi yazarların 1960'larda başlayan ve 1970 ve 1980'lerde iş dünyası ve şirketler üzerine yazdıkları yazılarında ortaya çıkmıştır.

Öğrenen Organizasyonların önemi, bileşenleri, bilginin boyutları konularında Peter Senge (Senge, 1990), John Seely Brown, Paul Duguid (Brown ve Duguid, 1991), David A. Garvin (Garvin, 1993), Victoria J. Marsick, Karen E. Watkins (Marsick ve Karen, 2003) gibi bu alanda isim yapmış yazarların yanı sıra, Kath Aspinwall, Tom Boydell, John Burgoyne, Alan Jones, Bob Garratt, Chris Hendry, David Lei, Ronnie Lessem, M. Marquardt, Michael E. McGil, Mike Pedler, A. Reynolds, John W. Slocum ve Penny West (Örtenblad, 2002) gibi araştırmacıların da önemli çalışmaları bulunmaktadır.

2000'li yıllara girildiğinde Öğrenen Organizasyon oluşumunun şartları, süreçleri ve faaliyet eşliğinde öğrenme teorileri ve pratiği Linda Holbeche (Holbeche, 1999), Lyle Yorks, Judy O'Neil (Yorks, O'Neil ve Marsick 1999), Verna J. Willis (Willis, 2001), Ikujior Nonaka (Nonaka ve Toyama, 2005), Peter E.D. Love, Jimmy Huang David J. Edwards Zahir Irani (Love ve diğerleri, 2005), Dale W. Lick (Lick, 2006) gibi önemli akademisyen ve iş dünyasından yöneticiler tarafindan işlenmiştir.

Öğrenen Organizasyon Uygulamalarının süreklilik arz edecek şekilde, takım halinde öğrenme sistematiğine dönüştürülmesi ve kurumsal kültürün bir parçası haline getirilmesi Paul Jackson (Jackson, 2010), Evrim Çalkavur (Çalkavur ve Durmuş 2015), Silvia Gherardi (Gherardi, 2015), Gregory G. Dess, Joseph C. Picken, Ho Wook Shin (Shin, Picken ve Dess, 2017) gibi isimlerin bu alanda derinleşmeleri ve pek çok kamu kurumu ve özel şirkette çalışanlar ve yöneticiler arasında uygulama firsatı bulmalarıyla mümkün olmuştur.

\section{2. Öğrenen Organizasyon Uygulama Takımları Nedir ve Neden Kullanılır?}

Senge modern organizasyonlarda temel öğrenme biriminin bireyler değil takımlar olduğunu ve organizasyonların öğrenmesinin takımların öğrenmesine bağlı olduğu söyler (Senge, 1990: 29). Öğrenmenin yeterince olup olmadığı ise çeşitli ölçme yöntem ve araçları ile belirlenebilir. Ölçmek için anket uygulaması yaygın bir tercih 
olup, yapılan araştırma sonucunda, "Öğrenen Organizasyon”, “Öğrenme Kültürü”, "Organizasyonel Değişim” gibi konularda pek çok farklı sektörde yüzlerce kurum üzerinde uygulanmış 21 adet anket belirlenmiş olup, anket sonuçlarının değerlendirme metodolojisi farlılıklar göstermektedir.

2008 yılında Garvin ve Edmondson tarafından geliştirilen “Öğrenen Organizasyon Anketi”, ise anketler üzerine yapılan literatür taramasında en sık kullanılan ve geçerliliği kanıtlanmış olan etkili bir ölçme aracı olarak öne çıkmaktadır. Söz konusu anketin kullanıldığı makaleler bu çalışmada detaylı bir şekilde incelenmiştir. İnceleme neticesinde anketin ABD, Kanada, Kosova ve Türkiye'de; mühendislik, hizmet, çevre ve sağlık sektörleri de dâhil pek çok şirket üzerinde başarıyla uygulandığı görülmüştür. $\mathrm{Bu}$ anketi hazırlayanlar ayrıca uygulayıcıların karşılaştırmalı değerlendirme (benchmark) yapabilmeleri için, özel bir ölçek geliştirmiştir (Cannon, 2012) (Garvin, 2008) (Qehaja, 2017) (Singer, 2012) (Tolgay, 2010) (Youthrex, 2016).

Uygulama Takımları özelinde bilgilerin yer aldığı ilk kaynak ise Garvin'in, Learning in Action: A Guide To Putting the Learning Organization to Work başl1klı çalışmasıdır. Garvin'e göre, yöneticiler öğrenen organizasyonların başarısına inanır ve değer verirler. ÖO kavramı bu yönüyle teoride kabul görmüştür. Buna rağmen kurumlarda öğrenen organizasyonların pratik uygulamaları nadiren görülmüştür. Garvin, bunun altında yatan sebebi, bu konudaki pratik uygulama rehberlerinin az sayıda ve yetersiz olmasına bağlar. Ona göre ÖOlar hakkındaki çalışmalar uygulamaya yönelik detaylı bilgi vermemektedir. $\mathrm{Bu}$ sebeple Garvin çalışmasında ÖO uygulamalarına ait pek çok sorunun cevabını çeşitli sektörlerden farklı ölçekteki firmaların uygulama şekillerinden örnekler vererek araştırır (Garvin, 1993).

\section{Şekil 1: Takım Halinde Öğrenme disiplinini diğer disiplinler ile etkileşimi}

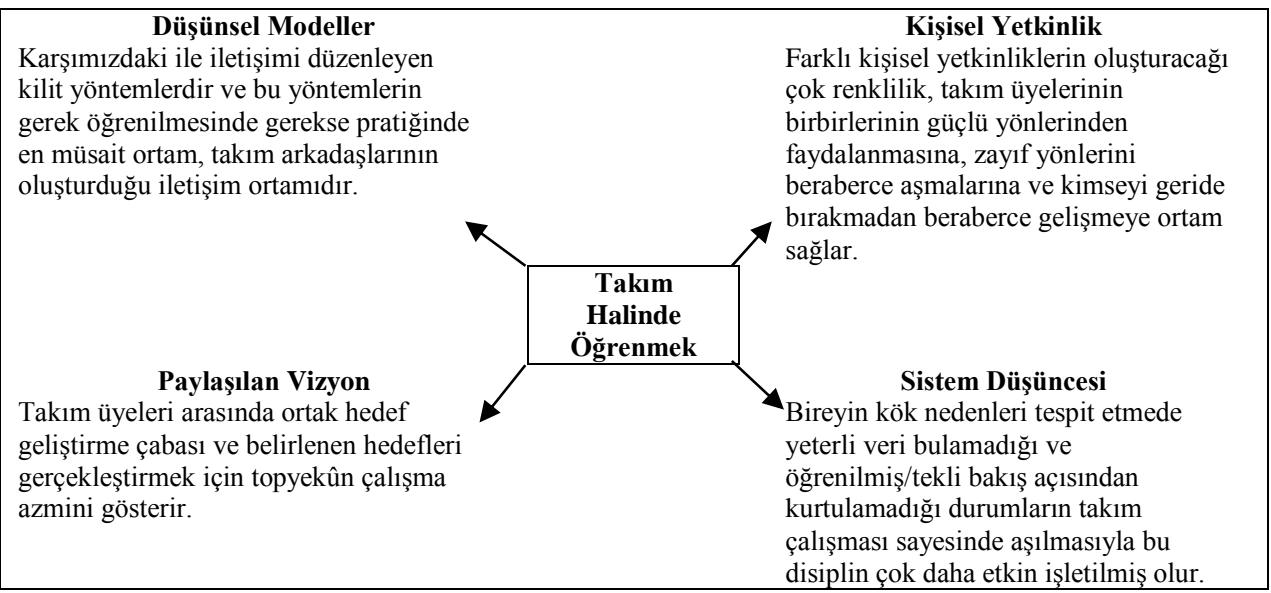


ÖO’un "Uygulama Takımları" yönteminde, öğrenme kültürünü uygulanan kurum içerisinde yaymak doğal bir hedef olarak benimsenmektedir. Bu felsefe ile bir kurumda ilk başta sadece bir adet uygulama takımı çalışmaya başlasa bile zamanla bu takım içerisinden bir veya birden fazla yeni uygulama takımı oluşması beklenir. Ayrıca, kurulmuş olan her takım özel bir kimliğe sahip olduğundan hedefler üzerindeki takip görevleri sürekli devam eder. Tabloda yer alan tanımlar ve prensipler birlikte ele alındığında ÖO Uygulama Takımlarını en geniş çerçevede "Bir organizasyonda önemli bir fayda oluşturmak için, ögrenmek ve ögretmek amacıyla bir araya gelen, birbirini dinleyen, sinerjiyle fikir üreten, bilgiye erişen ve bilgiyi dönüşü̈ren, yetkinliklerini sürekli geliştiren, değerleri ve kuralları olan, farklı birim ve kademelerden bireylerin oluşturduğu vizyon belirleyici sürekli takımlardır" şeklinde yeniden tanımlamak mümkündür.

Öğrenen örgütün varlığı ve uygulamasının uygulama takımları üzerinden nasıl yürütüldüğü yukarıda ayrıntılı olarak anlatılmıştır. Bu bağlamda şirketler gurubu üzerinden yürütülen araştırma/vaka çalışmasına bağlı olarak çalışmanın temel hipotezi ve alt hipotezleri öğrenen örgütler-uygulama takımları bağlamında şu şekilde ortaya konulmuştur:

Öğrenen organizasyon Uygulama Takımlarına sahip olan ve olmayan her biri farklı sektörde faaliyet gösteren bir şirketler grubunda görevli beyaz yaka personelin ve yöneticilerin organizasyonel öğrenme ve uygulamaları arasındaki farklılıklar bulunmaktadır.

Hipotez 1: Grup Şirketleri Bütününün “Öğrenme Ortamı” içerisinde gruplar arasında farklılıklar bulunmaktadır.

Hipotez 2: Somut Öğrenme Süreçleri ve Uygulamaları içerisinde gruplar arasında farklılıklar bulunmaktadır.

Hipotez 3: Öğrenmeyi Sağlamlaştıran Liderlik içerisinde gruplar arasında farkl11ıklar bulunmaktadır.

\section{Araştırma Yöntemi}

\subsection{Araştırmanın Yöntemi}

Araştırmada nicel yöntem kullanılmış olup, Araştırmada, Garvin, D.A., Edmondson, A.C. \& Gino, F.'nin, Harward Bussiness Review Dergisi'nin Mart-2008 sayısında yayınladığı, "Is Yours a Learning Organization?" adlı makalesinde, "3 Yapısal Blok" üzerine oluşturdukları anket ve bu anketin sonuçlarını değerlendirmede kullanılan Karşılaştırmalı Değerlendirme (benchmark) Tablosu, tercih edilmiştir. $\mathrm{Bu}$ tercihi destekleyen sebepler şunlardır;

- Literatürde en çok kullanılan anketlerden biridir.

- Katılımcılar açısından anketin cevaplandırılması kolay niteliktedir. 
- Anketin, online anket şeklinde tasarımı ve uygulanması kolaydır.

- $\mathrm{Bu}$ araştırmada hedeflenen grup şirketlerinde uygulanabilir özelliktedir.

\subsection{Puanlama Yöntemi}

Ankette Yapısal Blok 1 - Öğrenmeyi Destekleyici Ortam ve Yapısal Blok 2 Somut Öğrenme Süreçleri ve Uygulamaları'na ait 7'li ölçeğe verilen cevaplarda, cevabın karşılığı olarak 1'den 7'ye kadar aldığ 1 ham puan, 100 ile çarpılarak ve 7'ye bölünerek cevabın esas puan değeri hesaplanmıştır. Örneğin Yapısal Blok 1'de "[Bu şirkette aklınızdakileri rahatlıkla dile getirebilirsiniz.]" cümlesine "Kısmen Doğru" şeklinde cevap veren bir katılımcının puanı 6 x $100 / 7=86$ olarak bulunur.

Benzer şekilde Yapısal Blok 2 - Somut Öğrenme Süreçleri ve Uygulamaları'nde "[Bu şirkette yeni başlayan çalışanlar yeterli eğitimi alırlar.]" cümlesine "Genel Olarak Doğru” şeklinde cevap veren bir katılımcının puanı 5 x 100 / 7 $=71$ olarak bulunur.

Ankette Yapısal Blok 3 - Öğrenmeyi Sağlamlaştıran Liderlik'e ait 5'li ölçeğe verilen cevaplarda ise, cevabın karşılığ ile çarpılarak ve 5'e bölünerek cevabın esas puan değeri hesaplanmıştır. Örneğin Yapısal Blok 3'de "[Yöneticilerim derinlemesine araştıran sorular sorarlar.]" cümlesine "Nadiren" şeklinde cevap veren bir katılımcının puanı 2 x 100 / 5 = 40 olarak bulunur.

Ham puanlar verilirken bu yazının Araştırmada Kullanılan Yöntem bölümünde izah edilen 13 adet ters-puanlı sorunun ham puanları tersten verilmiştir. Örneğin Yapısal Blok 1'de “[Bu şirketteki insanlar aşırı stres altındadır.]” cümlesine "Kesinlikle Doğru” şeklinde cevap veren bir katılımcının puanı 1 x $100 / 7=14$ olarak bulunur.

\subsection{Karşılaştırmalı Değerlendirme (Benchmark) Tablosu}

Anket geliştiricilerin temel kabul ettiği kurumlardan elde edilen ve karşılaştırmalı değerlendirmede esas alınacak puanlar, önce ortalama bir puan olarak gösterilmiş, sonra bu ortalama değerin \%25'lik alt ve üst dilimleri oluşturulmuştur. Bunlar, “Alt Dilim”, “İkinci Dilim”, “Üçüncü Dilim” ve "Üst Dilim” adlarıyla 4 dilim olarak gösterilmiştir. Bu sayede anketi uygulayanlar puanlarının hangi puan dilim içine düştüğünü bularak, kurumdaki öğrenme düzeyinde mevcut durumun ve öncelikli beklentilerin kurumsal yansımasını tespit edebilmiş olur (Garvin, 2008).

Anket geliştiricilerin temel kabul ettiği kurumların verileri, Harvard Business School'da 8 haftalık bir genel yönetim programını tamamlayan çeşitli sektörlerden 225 üst düzey yöneticinin anketlerinden elde edilmiştir. Anketin istatistiksel özelliklerini test etmek ve yapısal altlığını belirlemek amacıyla 2006 baharında 100 üst düzey yöneticiye uygulanan anket sonuçları kullanılmıştır. Anketin uygulandığı birimde ya da şirkette anketin Yapısal Bloklara ya da Alt Bileşenlere ait sonuç puanları (Garvin, 2008).; 
- Eğer o Yapısal Blok ya da Alt Bileșenin temel gösterge niteliğindeki ortalama puan değerinin altında -özellikle de Alt Dilim'de- ise o alan üzerinde iyileştirme çalışması başlatılması beklenir. Zayıf noktaları iyileştirmek için kalıcı ve özel stratejiler geliştirecek bir beyin takımı oluşturulması tavsiye edilir.

- Eğer o Yapısal Blok ya da Alt Bileşenin temel gösterge niteliğindeki ortalama puan değerinin üstünde -özellikle de Üst Dilim'de- ise aynı alanda zayıf kalan diğer birimlerde ya da şirketlerde kalıcı ve özel stratejilerin geliştirilmesine yardımcı olacak bir ortak düşünce platformu modellenmesi tavsiye edilir.

- Puanların bu şekilde karşılaştırmalı değerlendirmeye tabi tutulması sayesinde, şirketler grubu genelinde, şirketlerde, birimlerde ve hatta bireylerde gelişimin, sürekli iyileştirmenin ve zirveye giden yolun önünü açacak firsatlar tespit edilmiş olur.

\section{Uygulama}

\subsection{Araştırma Hakkında Genel Bilgiler}

Hazırlanan anket, merkezi Konya/Türkiye'de olan, üçü Öğrenen Organizasyon Uygulama Takımlarına sahip olan ve dördü Öğrenen Organizasyon Uygulama Takımlarına sahip olmayan her biri farklı sektörde faaliyet gösteren yedi şirkette ve bu şirketleri bir grup olarak toplayan holding merkezinde görevli çalışan/uzman, orta ve üst kademe yöneticilere uygulanmıştır. Hazırlanan elektronik anket 10 gün süre ile erişime açılmış ve bu sürede 141 katılımcı anketi yanıtlamıştır. Katılımcıların anketi yanıtlamaları 15-20 dakika sürmüştür.

Tablo 4: Ankete Katılanların Çalıştığı Şirketlerin Sektörleri ve ÖO Uygulama Takımı Durumları

\begin{tabular}{|c|c|c|c|c|c|c|}
\hline No & Sektörü & $\begin{array}{c}\text { Katılımcı } \\
\text { Sayısı }\end{array}$ & $\begin{array}{c}\text { Katılımcı } \\
\text { Ağırlığı }\end{array}$ & $\begin{array}{c}\text { ÖO } \\
\text { Uygulama } \\
\text { Takımı }\end{array}$ & $\begin{array}{c}\text { Katılımeı } \\
\text { Sayısı }\end{array}$ & $\begin{array}{c}\text { Katılımcı } \\
\text { Ağırlığı }\end{array}$ \\
\hline 1 & İnşaat & 32 & $23 \%$ & \multirow{3}{*}{ Var } & \multirow{3}{*}{82} & \multirow{3}{*}{$58 \%$} \\
\hline 2 & Perakende & 26 & $18 \%$ & & & \\
\hline 3 & Gida & 24 & $17 \%$ & & & \\
\hline 4 & Diğer & 36 & $21 \%$ & \multirow{2}{*}{ Yok } & \multirow{2}{*}{59} & \multirow{2}{*}{$42 \%$} \\
\hline 5 & Holding Yönetim & 23 & $16 \%$ & & & \\
\hline & TOPLAM & 141 & $100 \%$ & TOPLAM & 141 & $100 \%$ \\
\hline
\end{tabular}

Tablo 4'de görüleceği gibi ankete katılanların \%23'ü İnşaat, \%18'i Perakende, \%17'si Gıda, \%21'i Diğer Sektörlerde (bilişim, makine, otomotiv, sigortacılık vb.), \%16's1 Holding Yönetim merkezinde görevlidir. 

Application in a Group of Companies

Bu şirketler grubunda, 2017-2018 döneminde, İnşaat şirketinde 1 adet, Perakende şirketinde 2 adet ve Gıda şirketinde 1 adet olmak üzere toplam 4 adet Öğrenen Organizasyon Uygulama Takımı kurulmuştur. $\mathrm{Bu}$ anlamda katılımcıların \%58'i Öğrenen Organizasyon Uygulama Takımları kültürünü başlatmış bir şirkette çalışmaktadır, \%42'si ise henüz Öğrenen Organizasyon Uygulama Takımları bulunmayan şirketler içinde yer almaktadır.

Şirketler grubunun beyaz yaka personel sayısı üst düzey yöneticiler hariç yaklaşık 500 kişidir ve bu anketin evreni olarak kabul edilmiştir. Ankete katılan 143 kişiden 2'sinini cevapları geçersiz olduğundan değerlendirmede sadece 141 anket sonucu dikkate alınmıştır. 141 adet cevaplama sayısı örneklem olarak 500 kişilik evrenin \%28,2'sini oluşturmaktadır. Betimsel araştırmalarda minimum \%10 örneklem alınması beklenir (Arlı: 2001). Bu kritere göre örneklemimiz oldukça yeterlidir.

\subsection{Kurumsal Bulguların Puanları ve Değerlendirmesi}

Anketin cevaplarının, puanlama yöntemine göre hesaplanmasıyla elde edilen puanlar, Karşılaştırmalı Değerlendirme Tablosu'na taşınarak yorumlanabilir hale getirilmiştir.

\subsubsection{Genel Puanların ve Yapısal Blok Puanlarının Karşılaştırmalı Değerlendirmesi}

Tablo 5'da görüleceği gibi Grup Şirketleri Bütünü, YB1 ve YB3'de "İkinci Dilim"de yer almasına rağmen YB2'de "Alt Dilim"in en üst sınırında yer almıştır. Genel Puanlamada ise Grup Şirketleri Bütünü “İkinci Dilim”de konumlanmıştır. Grup Şirketleri Bütününün Öğrenen Organizasyon olma özelliğini daha iyi anlamak için sektör bazında anket uygulanan İnşaat, Perakende ve Gıda Şirketlerinin de dilimlerine bak1lmalıdır. Tablo 5 incelendiğinde, İnşaat Şirketi YB1, YB2, YB3 ve Genel Puanlamada “Íkinci Dilim”de yer almıştır. İnşaat Şirketi YB1'in “İkinci Dilimi”nin en üst sınırında, ortalamaya çok yakın puanda bulunmaktadır. İnşaat Şirketi, tüm Yapısal Bloklar'da Grup Şirketleri Bütününün üzerinde puan almıştır. Tablo 14 incelendiğinde, Perakende Şirketi YB1 ve Genel Puanlamada "İkinci Dilim"de; YB2 ve YB3'de ise “Alt Dilim”de yer almıştır. Perakende Şirketi YB3'ün “Alt Dilimi”nin en üst sınırında bulunmaktadır. Perakende Şirketi, tüm Yapısal Bloklar'da Grup Şirketleri Bütününün altında puan almıştır. Tablo 5 incelendiğinde, Gıda Şirketi YB1, YB2 ve Genel Puanlamada “İkinci Dilim”de; YB3'de ise “Alt Dilim”de yer almıştır. Gıda Şirketi YB3'ün "Alt Dilimi”"nin en üst sınırında bulunmaktadır. Gıda Şirketi, YB1 ve YB3'de Grup Şirketleri Bütününün altında puan almıştır; bununla beraber YB2 ve Genel Puanlamada Grup Şirketleri Bütününü üzerinde puan almıştır. 


\subsubsection{Yapısal Blok 1 (Öğrenmeyi Destekleyici Ortam) ve Alt Bileşen Puanlarının Karşılaştırmalı Değerlendirmesi}

Tablo 5'da görüleceği gibi Grup Şirketleri Bütünü, YB1 - Öğrenme Ortamı Bileşik Puanında “İkinci Dilim”de yer almaktadır. Grup Şirketleri Bütünü, YB1'in Alt Bileşenleri incelendiğinde Yeni Fikirlere Açıklık'ta “Alt Dilim”de yer almıştır. Bunula beraber Farklılıkların Takdir Edilmesi'nde "İkinci Dilim"in en üst sınırında, Derinlemesine Düşünme Zamanı'nda ise “Üçüncü Dilim”in en üst sınırında puan almıştır. Grup Şirketleri Bütününün Öğrenmeyi Destekleyici Ortam özelliklerini daha iyi anlamak için sektör bazında anket uygulanan İnşaat, Perakende ve Gıda Şirketlerinin de dilimlerine bakılmalıdır. İnşaat Şirketi, YB1 - Öğrenme Ortamı Bileşik Puanında "İkinci Dilim”de yer almaktadır. İnşaat Şirketi, YB1'in Alt Bileşenleri İncelendiğinde Yeni Fikirlere Açıklık'ta “Alt Dilim”de yer alırken, Psikolojik Güven'de ise "İkinci Dilim"in en üst sınırında puan almıştır. Ayrıca, Farklılıkların Takdir Edilmesi'nde “Üçüncü Dilim”de, Derinlemesine Düşünme Zamanı'nda ise “Üst Dilim”de konumlanmıştır.

Perakende Şirketi, YB1 - Öğrenme Ortamı Bileşik Puanında “İkinci Dilim”de yer almaktadır. Perakende Şirketi, YB1'in Alt Bileşenleri İncelendiğinde Yeni Fikirlere Açıklık'ta “Alt Dilim”de yer alırken, Farklılıkların Takdir Edilmesi'nde “İkinci Dilim"in en üst sınırında, Derinlemesine Düşünme Zamanı'nda ise "Üçüncü Dilim"in en üst sınırında puan almıştır. Gıda Şirketi, YB1 - Öğrenme Ortamı Bileşik Puanında “İkinci Dilim”de yer almaktadır. Gıda Şirketi, YB1'in Alt Bileşenleri İncelendiğinde Yeni Fikirlere Açıklık'ta “Alt Dilim”de yer alırken, Farklılıkların Takdir Edilmesi'nde “Íkinci Dilim”in üst sınırında, Derinlemesine Düşünme Zamanı'nda ise "Üçüncü Dilim"de yer almıştır. 
Tablo 5: Sonuçlar ve Puan Değerlendirme Tablosu

\begin{tabular}{|c|c|c|c|c|c|c|c|c|c|}
\hline \multirow{2}{*}{ Yapısal Bloklar ve Alt Bileşenleri } & \multicolumn{3}{|c|}{ Şirketin Sektörü } & \multirow{2}{*}{$\begin{array}{c}\text { Grup } \\
\text { Şirketlerinin } \\
\text { Bütünü }\end{array}$} & \multicolumn{5}{|c|}{$\begin{array}{l}\text { Karşılaştırmalı Değerlendirme Tablosu } \\
\text { (Garvin, 2008: 5) }\end{array}$} \\
\hline & İnşaat & Perakende & Gida & & $\begin{array}{c}\text { Alt } \\
\text { Dilim }\end{array}$ & $\begin{array}{l}\text { İkinci } \\
\text { Dilim }\end{array}$ & Ortalama & $\begin{array}{l}\text { Üçüncü } \\
\text { Dilim }\end{array}$ & Üst Dilim \\
\hline \multicolumn{10}{|c|}{ YAPISAL BLOK 1 - Öğrenmeyi Destekleyici Ortam } \\
\hline Psikolojik Güven & 75 & 72 & 72 & 73 & $31-66$ & $67-75$ & 76 & $77-86$ & $87-100$ \\
\hline Farklılıkların Takdir Edilmesi & 67 & 62 & 61 & 63 & $14-56$ & $57-63$ & 64 & $65-79$ & $80-100$ \\
\hline Yeni Fikirlere Açıklık & 66 & 65 & 65 & 64 & $38-80$ & $81-89$ & 90 & $91-95$ & $96-100$ \\
\hline Derinlemesine Düşünme Zamanı & 69 & 63 & 59 & 64 & $14-35$ & $36-49$ & 50 & $51-64$ & $65-100$ \\
\hline Öğrenme Ortamı Birleşik Puanı & 69 & 65 & 65 & 66 & 31-61 & $62-70$ & 71 & 72-79 & $80-90$ \\
\hline \multicolumn{10}{|c|}{ YAPISAL BLOK 2 - Somut Öğrenme Süreçleri ve Uygulamaları } \\
\hline Deneme & 63 & 63 & 68 & 63 & $18-53$ & $54-70$ & 71 & $72-82$ & $83-100$ \\
\hline Bilgi Toplama & 62 & 65 & 70 & 66 & $23-70$ & $71-79$ & 80 & $81-89$ & $90-100$ \\
\hline Analiz & 66 & 61 & 63 & 63 & $19-56$ & $57-70$ & 71 & $72-86$ & $87-100$ \\
\hline Eğitim ve Öğretim & 58 & 57 & 60 & 58 & $26-68$ & $69-79$ & 80 & $81-89$ & $90-100$ \\
\hline Bilgi Aktarma & 67 & 50 & 63 & 60 & $34-60$ & $61-70$ & 71 & $72-84$ & $85-100$ \\
\hline Öğrenme Süreci Birleşik Puanı & 64 & 59 & 64 & 62 & 31-62 & $63-73$ & 74 & $75-82$ & 83-97 \\
\hline \multicolumn{10}{|c|}{ YAPISAL BLOK 3 - Öğrenmeyi Sağlamlaştıran Liderlik } \\
\hline Öğreten Liderlik Birleşik Puanı & 70 & 66 & 65 & 67 & $33-66$ & $67-75$ & 76 & 77-82 & $83-100$ \\
\hline GENEL PUAN * & 66 & 62 & 65 & 64 & $31-61$ & $62-70$ & 71 & 72-78 & $79-93$ \\
\hline
\end{tabular}

* Grup Şirketleri Bütününün, 3 yapısal blok için birleşik puanlarının genel puana indirgenmesi için bulunan katsayı "0,323038219310809"dir. Bu katsayısının Garvin, D.A., Edmondson, A.C. \& Gino, F.'nin Karşılaştırmalı Değerlendirme Tablosu'nda bulunan dilimlerin en küçük ve en büyük değeri ile çarpılması ile bulunan değerler araştırmaya özel GENEL PUAN ölçeği olarak kabul edilmiştir. 
Öğrenen Organizasyonların Anlaşılmasında ve Başarısında Bir Yöntem Olarak Uygulama Takımları: Bir Sirketler Grubunda Uygulama

Anket puanları YB1'yi oluşturan kurumsal cümleler bazında değerlendirildiğinde çalışanların karakteristikleri aşağıdaki bulgulardan ortaya çıkarılmış olur; İkinci Dilimde kalan Grup Şirketleri Bütününün en yüksek puanlı kurumsal kısa cümlesinin "İş yüküne rağmen, bu şirketteki insanlar, işlerin nasıl gittiğini gözden geçirmeye zaman bulur." olduğu; en düşük puanlı kurumsal kısa cümlesinin "Bu şirkette insanlar, denenmemiş yöntemlere sıklıkla direnirler." olduğu görülmüştür. İkinci Dilimde kalan İnşaat Şirketi'nin en yüksek puanlı kurumsal kısa cümlelerinin "İ̧s yüküne rağmen, bu şirketteki insanlar, işlerin nasıl gittiğini gözden geçirmeye zaman bulur." ve "Bu şirkette, insanlar iş yapmanın alternatif yollarına açıktır." olduğu; en düşük puanlı kurumsal kısa cümlesinin "Bu şirkette insanlar, denenmemiş yöntemlere sıklıkla direnirler." olduğu görülmüştür. İkinci Dilimde kalan Perakende Şirketi’nin en yüksek puanlı kurumsal kısa cümlesinin "İş yüküne rağmen, bu şirketteki insanlar, işlerin nasıl gittiğini gözden geçirmeye zaman bulur." olduğu; en düşük puanlı kurumsal kısa cümlesinin " $\mathrm{Bu}$ şirkette insanlar, denenmemiş yöntemlere sıklıkla direnirler." olduğu görülmüştür. İkinci Dilimde kalan Gıda Şirketi'nin en yüksek puanlı kurumsal kısa cümlesinin "İş yüküne rağmen, bu şirketteki insanlar, işlerin nasıl gittiğini gözden geçirmeye zaman bulur." olduğu; en düşük puanlı kurumsal kısa cümlesinin "Bu şirkette insanlar, denenmemiş yöntemlere sıklıkla direnirler.” olduğu görülmüştür.

\subsubsection{Yapısal Blok 2 (Somut Öğrenme Süreçleri ve Uygulamaları) ve Alt Bileşen Puanlarının Karşılaştırmalı Değerlendirmesi}

Tablo 5'da görüleceği gibi Grup Şirketleri Bütünü, YB2 - Öğrenme Süreci Bileşik Puanında "Alt Dilim"in en üst sınırında puan almıştır. Grup Şirketleri Bütünü, YB2'nin Alt Bileşenleri incelendiğinde Bilgi Toplama'ta ve Eğitim ve Öğretim'de "Alt Dilim"de yer alırken, Bilgi Aktarma'da ise "Alt Dilim"in en üst sınırında puan almıştır. Bununla beraber, Deneme'de ve Analiz'de “İkinci Dilim”de yer almıştır. Grup Şirketleri Bütününün Somut Öğrenme Süreçleri ve Uygulamalarına dair özelliklerini daha iyi anlamak için sektör bazında anket uygulanan İnşaat, Perakende ve Gıda Şirketlerinin de dilimlerine bakılmalıdır.

İnşaat Şirketi, YB2 - Öğrenme Süreci Bileşik Puanında "İkinci Dilim”de yer almaktadır. İnşaat Şirketi, YB2'in Alt Bileşenleri İncelendiğinde Bilgi Toplama'ta ve Eğitim ve Öğretim'de “Alt Dilim”de yer almıştır. Perakende Şirketi, YB2 - Öğrenme Süreci Bileşik Puanında "Alt Dilim”de yer almaktadır. Perakende Şirketi, YB2'in Alt Bileşenleri İncelendiğinde Deneme'de ve Analiz'de “İkinci Dilim”de yer almıştır. Gıda Şirketi, YB2 - Öğrenme Süreci Bileşik Puanında "İkinci Dilim”de yer almaktadır. Gıda Şirketi, YB2'in Alt Bileşenleri incelendiğinde Eğitim ve Öğretim'de “Alt Dilim”de yer alırken, Bilgi Toplama'da "Alt Dilim”in en üst sınırında puan almıştır.

Anket puanları YB2'yi oluşturan kurumsal cümleler bazında değerlendirildiğinde takımların ya da kurumsal süreçlerin karakteristikleri aşağıdaki bulgulardan ortaya çıkarılmış olur; Alt Dilimde kalan Grup Şirketleri Bütününün en yüksek puanlı kurumsal kısa cümlesinin "Bu şirkette görüşmeler/toplantılar esnasında, farklı görüşler 
mutlaka dikkatle dinlenir." olduğu; en düşük puanlı kurumsal kısa cümlesinin "Bu şirketteki tecrübeli çalışanlar yeni bir göreve getirildiğinde eğitim alırlar." olduğu görülmüştür. İkinci Dilimde kalan İnşaat Şirketi'nin en yüksek puanlı kurumsal kısa cümlesinin "Bu şirkette, taşeron ve tedarikçiler ile görüşmek ve onlardan öğrenmek için oturumlar yapılır." olduğu; en düşük puanlı kurumsal kısa cümlesinin "Bu şirketteki tecrübeli çalışanlar yeni bir göreve getirildiğinde eğitim alırlar.” olduğu görülmüştür. Alt Dilimde kalan Perakende Şirketi'nin en düşük puanlı kurumsal kısa cümlesinin "Bu şirkette, taşeron ve tedarikçiler ile görüşmek ve onlardan öğrenmek için oturumlar yapılır." olduğu görülmüştür. İkinci Dilimde kalan Gıda Şirketi’nin en yüksek puanlı kurumsal kısa cümlesinin "Bu şirkette, yeni ürün ve hizmet teklifleri çoğu kez denenir." olduğu; en düşük puanlı kurumsal kısa cümlesinin "Bu şirketteki tecrübeli çalışanlar yeni bir göreve getirildiğinde eğitim alırlar.” olduğu görülmüştür.

\subsubsection{Yapısal Blok 3 (Öğrenmeyi Sağlamlaştıran Liderlik) Puanlarının Karşılaştırmalı Değerlendirmesi}

Tablo 5'da görüleceği gibi Grup Şirketleri Bütünü, YB3 - Öğreten Liderlik Bileşik Puanında “İkinci Dilim”de yer almıştır. Grup Şirketleri Bütününün Öğrenmeyi Sağlamlaştıran Liderlik özelliklerini daha iyi anlamak için sektör bazında anket uygulanan İnşaat, Perakende ve Gıda Şirketlerinin de dilimlerine bakılmalıdır. YB3 Öğreten Liderlik Bileşik Puanında, İnşaat Şirketi “İkinci Dilim”de yer alırken, Perakende Şirketi ve Gıda Şirketi “Alt Dilim”in üst sınırında puan almıştır. Anket puanları YB3'ü oluşturan kurumsal cümleler bazında değerlendirildiğinde yöneticilerin karakteristikleri aşağıdaki bulgulardan ortaya çıkarılmış olur; İkinci Dilimde kalan Grup Şirketleri Bütününün en yüksek puanlı kurumsal kısa cümlesinin "Yöneticilerim dikkatlice dinler" olduğu; en düşük puanlı kurumsal kısa cümlesinin "Yöneticilerim geçmiş performans üzerinde derinlemesine düşünmek ve ilerleme sağlamak için zaman, kaynak ve ortam temin eder." olduğu görülmüştür.

İkinci Dilimde kalan İnşaat Şirketi’nin en yüksek puanlı kurumsal kısa cümlesinin "Yöneticilerim dikkatlice dinler" olduğu; en düşük puanlı kurumsal kısa cümlesinin "Yöneticilerim sorunları ve kurumsal zorlukları tespit etmek için zaman, kaynak ve ortam temin eder." olduğu görülmüştür. Alt Dilimde kalan Perakende Şirketi'nin en düşük puanlı kurumsal kısa cümlesinin "Yöneticilerim, kendi görüşlerinden farklı görüşleri eleştirir." olduğu görülmüştür. Alt Dilimde kalan Gıda Şirketi'nin en düşük puanlı kurumsal kısa cümlesinin "Yöneticilerim geçmiş performans üzerinde derinlemesine düşünmek ve ilerleme sağlamak için zaman, kaynak ve ortam temin eder." olduğu görülmüştür.

\section{Sonuç}

Grup Şirketleri Bütününün “Öğrenme Ortamı” ile ilgili karakteristik özelliği değerlendirildiğinde: 
Öğrenen Organizasyonların Anlaşılmasında ve Başarısında Bir Yöntem Olarak Uygulama Takımları: Bir Şirketler Grubunda Uygulama

Araştırma, Konya'da faaliyet gösteren şirketler grubunun holdingde, uygulama takımı olan sadece inşaat, perakende, gıda gruplarındaki beyaz yakalılar üzerinde yapılmıştır. Çalışmanın temel ve alt hipotezleri bu kısıtlar çerçevesinde test edilmiş ve kabul edilmiştir. Hipotezlerin değerlendirilmesine ilişsin: İnşaat, Gıda ve Perakende Şirketlerinin çalışanlıları, günlük yoğun tempodaki iş yüklerine rağmen, iş süreçleri üzerinde yeniden düşünmeye, süreçleri değerlendirmeye özen göstermektedir. Tüm şirketler genelinde kabul görmüş bu karakteristik özellik devam ettirilmelidir. İnşaat, Gıda ve Perakende Şirketlerinin çalışanlılarından daha önce denenmemiş yöntemleri uygulaması istendiğinde, çalışanların buna direndikleri, risk almak istemedikleri ve dolayısıyla işlerine dair daha kolay ya da verimli olabilecek yöntemleri keşfedemedikleri görülmüştür. Çalışanların bu algısının varlığı tüm Şirketler Grubunda tespit edilmiştir. ÖO Uygulama Takım üyelerinden başlayarak dış koçların da desteği ile çalışanların bu zayıf algısı dönüştürülmeye başlanmalıdır. Yöneticiler, çalışanlarının risk alarak denenmemiş yöntemlere iş yapmalarını istediğinde risk alarak bunu deneyen çalışanlar desteklenmeli ve bu deneme sonucunda başarısız olunsa bile çalışanlar denemekten vazgeçmediği için onların cesaretleri kırılmamalıdır. Yeni denemelerin sonuçlarının mutlaka öğrenilmiş ders olarak kurum hafızasına alınmasını sağlayacak ortam oluşturmalıdır. Böylece yeni denenen yöntemin oluşturduğu fayda genele yayılmaya başlar ve bunu tatbik eden çalışanlar takdir edilerek diğer çalışanların dirençleri kırılmış ve hevesleri arttırılmış olur. Ayrıca İnşaat Şirketi çalışanlarının, işlerini yaparlarken alternatif yollar ve B planı oluşturmada çok esnek olduğu ve bunun benimsenmiş bir özellik olduğu görülmüş̧ür. Diğer grup şirketlerinin çalışanlarında da bu özelliğin geliştirilebilmesi için İnşaat Şirketinin ÖO Uygulama Takım üyelerinin ya da koçlarının diğer şirketlerin ÖO Uygulama Takımı toplantılarına davet edilerek, takım çalışmaları esnasında alternatif fikirler üretmeleri konusunda ÖO gruplarına örnek olması sağlanabilir.

Grup Şirketleri Bütününün “Öğrenme Süreci” ile ilgili karakteristik özelliği değerlendirildiğinde:

İnşaat Şirketinde, iş süreçlerinin parçası olarak mutlaka taşeron ve tedarikçiler ile görüşüldüğü ve onların bilgi birikiminden istifade edildiği görülmüştür. Bunun aksine, bu özelliğin Perakende Şirketi'nin süreçleri içinde en zayıf işletilen özellik olduğu tespit edilmiştir. Perakende Şirketi'ne İnşaat Şirketi'nden taşeron ve tedarikçi oturumlarına dair yöntemler hakkında destek alarak süreçlerine taşeron ve tedarikçilerinden öğrenme özelliğini dâhil etmesi tavsiye edilir. İnşaat Şirketindeki ve Gıda Şirketindeki eğitim süreçlerinde, tecrübeli çalışanların yeni bir göreve atandıklarında o göreve ilişsin ön eğitim almalarına dair planlama yapılmadığı tespit edilmiştir. Bu durumun Şirketler Grubu Bütününde de benzer durumda olduğu görülmüştür. Eğitim süreçlerinde, tecrübeli çalışanların da gelişimleri planlanmalı, onların eğitim ve öğretimleri desteklenmelidir. Çalışanlar tecrübeli olsalar dahi yeni bir göreve getirildiklerinde onların, eğer benzer görevde başka bir çalışan varsa öncelikle o çalışandan, eğer görevi bir başkasında devralıyorsa bir önceki görevli çalışandan ve eğer bu görev şirkette yeni açılan bir pozisyon ise konusunda uzman dış eğitmenlerden eğitim alması ve 
oryantasyona tabi tutulması sağlanmalıdır. Gıda Şirketi'nde teklif edilen yeni ürün ve hizmetlerin sıklıkla denendiği ve bunun şirketin ürün ve hizmet çeşitliliğine ve çalışan tecrübesine katkısı olduğu görülmüş̧ür. Gıda Şirketi'nin bu özelliğinin ve faydalarının diğer şirketler ile paylaşılması, diğer şirketlerin yenilikçi kabiliyetlerinin artmasına ve öğrenme düzeylerinin üst dilimlere taşınmasına katkı sağlayacaktır.

Grup Şirketleri Bütününün “Öğreten Liderlik” ile ilgili karakteristik özelliği değerlendirildiğinde:

İnşaat Şirketi yöneticilerinin çalışanlarını dikkatle dinlemesi takdir edilmeli ve diğer şirketler yöneticilerine örnek gösterilmelidir. İnşaat Şirketi'nin yöneticileri çalışanların şirketteki sorunları ve zorlukları tespit edebilmesi için yeteli zaman ve ortamı oluşturmalıdır. Perakende Şirketi'nin yöneticileri kendi görüşlerinden farklı görüşleri hoşgörü ile karşılamalıdır. Gıda Şirketi'nin yöneticileri şirketin performansını daha iyi gözlemlemeli ve dönemlik sonuçlar üzerinde derinlemesine düşünerek ve performansın geliştirilmesi için çalışanlara yeterli zaman ve ortam oluşturmalıdır.

Genel amaca uygun olarak, seçilen şirketler grubuna tatbik edilen anket çalışması ve analizi ile hem uygulamada hem de yorumlamada örnek bir çalışma ortaya konulmuştur. Söz konusu grup şirketlerinin Öğrenen Organizasyon Uygulama Takımları'na dair süreçlerinin incelenmesi ve organizasyonel öğrenme seviyelerinin ölçümlenmesi bir kurumun neden Öğrenen Organizasyon olması gerektiğine dair bize önemli ipuçları vermiştir.

Aynı anketi kısaltılmış şekilde hizmet sektörü çalışanları üzerinde uygulayan Tolgay, bu sektördeki organizasyonların en düşük değerdeki özelliğinin YB2'nin Alt Bileşeni olan “Eğitim ve Öğretim” olduğunu tespit etmiştir (Tolgay: 2010). Araştırmada anket araştırmasına konu İnşaat Şirketi, Perakende Şirketi ve Gıda Şirketi için de en düşük değerdeki özelliğin yine YB2'nin Alt Bileşeni olan "Eğitim ve Öğretim” olarak tespit edilmesi, anketlerin farklı sektörlerde de olsa benzer sonuçları verdiğini göstermiştir.

Qehaja, Kosova ve Hırvatistan'da üretim, ticaret ve hizmet sektöründe faaliyet gösteren KOBI'ler üzerinde yaptığı araştırmada aynı anketi kullanmış ve her iki ülkedeki KOBİ’lerin YB1 - Öğrenmeyi Destekleyici Ortam açısından benzer özelliklere sahip olduklarını ve genel değerlendirmede "İkinci Dilim"de yer aldığını tespit etmiştir (Qehaja: 2017). Bizim araştırmamız da hem İnşaat, Perakende ve Gıda Şirketlerinin ayrı ayrı hem de Grup Şirketlerinin Bütünün birbirine en benzer özellikte olduğu yapısal bloğun YB1 olduğunu göstermektedir. Ayrıca araştırmamızın genel sonucunda hem İnşaat, Perakende ve Gıda Şirketlerinin ayrı ayrı hem de Grup Şirketlerinin Bütünü “İkinci Dilim”de yer almıştır. Bu durum Qehaja’nın farklı ülkelerde ve farklı sektörlerde elde ettiği sonuçlarla paralellik göstermektedir.

$\mathrm{Bu}$ iki örnek faaliyet gösterdiği sektör ve ülke ne olursa olsun bir şirketin Öğrenen Organizasyon olma yolunda yapması gerekenlerin benzer süreçler olduğunu ortaya koymaktadır. Öğrenen Organizasyon Uygulama Takımları'na sahip olan 
Öğrenen Organizasyonların Anlaşılmasında ve Başarısında Bir Yöntem Olarak Uygulama Takımları:

ARICIOĞLU \& HELVACIOĞLU Bir Sirketler Grubunda Uygulama

işletmelerin organizasyonel öğrenme düzeylerini çok daha hızlı şekilde üst düzeye taşıyabileceği, çalışanlar, takımlar, süreçler ve liderler özelinde eş zamanlı yapılacak iyileştirmelerin değişimin ve yeniliğin işletme içerisinde sürekli hale gelmesinin yolunu açacağı görülmüştür. Dinamik bir değişim kabiliyetinin bugünün işletmelerinde rekabet için başlica aranan özellik olduğu bilindiğinde bu husustaki araştırma ve uygulama çabaları daha da değerli hale gelmiştir. Önemli olan kurumun bu yolculukta öğrenme kabiliyetlerini diri tutması ve çalışanlarına sabırla öğrenmeyi sevdirmesidir. Öğrenen Organizasyon Uygulama Takımları bu amaca hizmet eden en iyi kurumsal donanımlardan biri olma yolundadır. Her meselede olduğu gibi bu yöntemin de süreçleri içinde geliştirilmesi gereken yönleri vardır. Uygulamalar arttıkça ortaya çıkacak geliştirilmeye müsait yönler, bu yöntemleri daha da güçlü kurumsal bileşenlere dönüştürecektir.

Özellikle uygulama takımlarında rol alan çalışanların performans ölçümlerinde, çalışanın kurumun öğrenme kültürüne katkısı ve bireysel yetkinliklerini nasıl geliştirdiği değerlendirmeye alınmalıdır. Tüm bu okumalar, araştırmalar, örneklemeler, analiz ve sonuçlar birlikte düşünüldüğünde, daha önce bu alanda yapılan çalışmalara ilaveten:

- Öğrenen Organizasyon kavramını günümüz koşulları ile yeniden tanımlayarak,

- Farklı uzmanların Öğrenen Organizasyon algısına dair ortak noktalarını tespit ederek,

- Organizasyonel Öğrenme ile Öğrenen Organizasyon farkının daha net algılanmasını sağlayarak,

- Çeşitli Öğrenen Organizasyon ölçme araçlarını bir arada sunarak,

- Öğrenen Organizasyonların öğrenme özelliklerinin Geleneksel Kurumlardan ayrıştığı noktaları tespit ederek,

- Öğrenen Organizasyon Uygulama Takımları'nın nasıl bir ihtiyaçla ve modelle ortaya çıktığını inceleyerek,

- Öğrenen Organizasyon Uygulama Takımları'nın özellikleri üzerinde derinleşerek,

- Öğrenen Organizasyon anketinin kapsamlı bir uygulamasını ve değerlendirmesini barındırarak

literatüre katkı sağlamış ve araştırmacı şirketlere faydalı bir çalışma ortaya koyulmuştur.

\section{Kaynakça}

Aase, K. (1998). Handbooks As A Tool for Organizational Learning; A Case Study. Stavanger: Norwegian University of Science and Technology. 
Anand, G., Ward, P.T., Tatikonda, M.V. ve Schilling, D.A. (2009). Dynamic Capabilities Through Continuous Improvement Infrastructure. Journal of Operations and Management, 2009(27), 444-461.

Argyris, C. (1977). Organisational Learning And Management Information Systems. Accounting, Organisations And Society, 2(2), 113-123.

Arlı, M. ve Nazik, H. (2001). Bilimsel Araştırmaya Giriş. Ankara: Gazi Kitabevi.

Bont1s, N., Crossan, M.M. ve Hulland, J. (2002). Managing an Organizational Learning System by Aligning Stocks and Flows of Knowledge. Journal of Management Studies, 39(4), 437-469.

Brown, J.S. ve Duguid, P. (1991). Organizational Learning and Communities-ofPractice; Toward a Unified View of Working, Learning, and Innovation. Organization Science, 2(1), 40-57.

Cannon, M. (2012). Learning Organization Characteristics Assessment. Tennessee: Vanderbilt Üniversitesi.

Çalkavur, E. (2006). Öğrenen Organizasyon Yolculuğu Bir Başarı Öyküsü, 7. Bask1, İstanbul: Remzi Kitabevi

Çalkavur, E. ve Durmuş M.Y. (2015). Alan Derin Bir Nefes, 1. Baskı, İstanbul: Remzi Kitabevi

Çınar, F. ve Eren E. (2015). Organizational Learning Capacity Impact on Sustainable Innovation; The Case of Public Hospitals. Procedia - Social and Behavioral Sciences, 2015(181), 251-260.

Dikmen, Ç. (1999). Organizasyonel Öğrenme ve Öğrenen Organizasyonlar. Yönetim, 10(34), 57-67.

Garvin, D.A. (1993). Building A Learning Organization. Harward Business Review, Temmuz-A $\breve{g}$ ustos 1993(71), 1-15.

Garvin, D.A. (2000). Learning in Action: A Guide to Putting the Learning Organization to Work. Boston: Harvard Business School Press.

Garvin, D.A., Edmondson, A.C. ve Gino, F. (2008). Is Yours a Learning Organization. Harward Business Review, March 2008, 1-10.

Gherardi, S. (2015). Learning; Organizational. International Encyclopedia of the Social \& Behavioral Sciences, 2nd Edition, 13, Trento: University of Trento. 
Öğrenen Organizasyonların Anlaşılmasında ve Başarısında Bir Yöntem Olarak Uygulama Takımları: Bir Sirketler Grubunda Uygulama

ARICIOĞLU \& HELVACIOĞLU

Competencies in Authentic Academic Libraries, (ss. 111-124), ABD: Chandos Publishing.

Gordon, E.E. (2012). Skill Wars. London: Routledge.

Henri, J., Asselin M. (2005). The Information Literate School Community 2. Issues of Leadership. ABD: Libraries Unlimited

Henrich, K.J. ve Attebury R. (2010). Communities of Practice at an Academic Library; A New Approach to Mentoring at the University of Idaho. The Journal of Academic Librarianship, 36(2), 158-165.

Heydebrand, Wolf. (2009). Accounting for Great Expectations; Lessons from the New Media Surge for Critical Management Theory. Critical Perspectives on Accounting, 2009(20), 418-444.

Holbeche, Linda (1999). Aligning Human Resources and Business Strategy. 2. Bask1, Burlington: Butterworth-Heinemann

Holbeche, Linda (2006). Understanding Change_ Theory, Implementation and Success. Burlington: Butterworth-Heinemann

Jackson, P. (2010). Web 2.0 Knowledge Technologies and the Enterprise; Smarter, Lighter and Cheaper. ABD: Chandos Publishing

Kaya, N. (2015). Öğrenen Organizasyon, Yenilik Ve Değişim Mühendisliği Uygulamalarının Firma Performansı Üzerindeki Etkileri. İstanbul: Beykent Üniversitesi, Sosyal Bilmler Enstitüsü.

Koizumi, M. (2017). Inherent Strategies in Library Management. ABD: Chandos Publishing.

Kuşcu, Z.K., Yener, M. ve Gürbüz, F.G. (2015). Learning Organization and its Cultural Manifestations; Evidence from a Global White Goods Manufacturer. Procedia Social and Behavioral Sciences, 2015(210), 154-163.

Li, T. ve diğerleri (2016). Study on Multi-agent Based Simulation of Team Machine Learning. Procedia Computer Science, 2016(91), 847-854.

Lick, D.W. (2006). A New Perspective on Organizational Learning; Creating Learning Teams. Evaluation and Program Planning, 2006(29), 88-96.

Love, P.E.D ve diğerleri (2005). Management of Knowledge in Project Environments. 1.Bask1, Burlington: Butterworth-Heinemann. 
Mahmud, N. ve Hilmi M.F. (2014). TQM and Malaysian SMEs Performance; The Mediating Roles of Organization Learning. Procedia - Social and Behavioral Sciences, 2014(130), 216-225.

Marsick, V.J. ve Karen E.W. (2003). Demonstrating the Value of an Organization's Learning Culture; The Dimensions of the Learning Organization Questionnaire. Advances in Developing Human Resources, 2003(5), 132-151.

Murray, M.F., Havener, J.-M., Davis, P.S., Jastremski, C., \& Twichell, M.L. (2011). The Rural Pipeline; Building a Strong Nursing Workforce Through Academic and Service Partnerships. Nurs Clin N Am, 2011(46), 107-121.

Nonaka, I. ve Toyama, R. (2005). The Theory of the Knowledge-Creating Firm: Subjectivity, Objectivity and Synthesis. Industrial and Corporate Change, 14(3), 419-436.

Orange, G., Cushman M. ve Burke A. (2009). COLA: A Cross Organisational Learning Approach within UK Industry. Birleşik Krallık: The London School of Economics and Political Science.

Orange, G., Burke A. ve Boam J. (2000). The Facilitation of Cross Organisational Learning and Knowledge Management to Foster Partnering within the UK Construction Industry. Birleşik Krallık: Leeds Metropolitan Üniversitesi.

O'neil, J. ve Lamm, S. (2001). Comparing the Learner's and Educator's Perspective on Conditions that Foster Transformative Learning in Action Learning Programs. Academy of Human Resourse Development, 2001, 1-3.

Örtenblad, A. (2002). A Typology of the Idea of Learning Organization. Management Learning, 33(2), 213-230.

Pant, Laurie.W. (2001). The Growing Role of Informal Controls Does Organization Learning Empower or Subjugate Workers. Critical Perspectives on Accounting, 2001(12), 697-712.

Pitelis, C.N. (2007). A Behavioral Resource-Based View of the Firm: The Synergy of Cyert and March (1963) and Penrose (1959). Organization Science, 18(3), 478490.

Qehaja, A.B., Kutllovci, E. ve Havolli, Y. (2017). Learning Organization Survey; A Study in Kosovan Enterprises. Godina: Zbornik Ekonomskog fakulteta u Zagrebu.

Rhodes, C. (1997). Playing with Words: Multiple Representations of Organisational Learning Stories. Electronic Journal of Radical Organization Theory, 3(1), 1-26. 
Öğrenen Organizasyonların Anlaşılmasında ve Başarısında Bir Yöntem Olarak Uygulama Takımları:

ARICIOĞLU \& HELVACIOĞLU Bir Sirketler Grubunda Uygulama

Sadler-Smith, E., Chaston, I. ve Spicer, D.P. (1999). Organisational Learninig in Smaller Firms: An Emprical Perspective. Plymouth: Plymouth Ünivesitesi, İşletme Okulu.

Senge, P. (1990). Beşinci Disiplin. 19. Baskı, İstanbul: Yapı Kredi Yayınları.

Shin, H.W., Picken J.J. ve Dess G.G. (2017). Revisiting the Learning Organization. Organizational Dynamics, 46(1), 46-56.

Schein, E.H. (1996). Three Cultures of Management: The Key to Organizational Learning. Sloan Management Review, 38(1), 11-16.

Singer, S.J., Moore, S.C., Meterko, M. ve Williams, S. (2012). Development of a ShortForm Learning Organization Survey; The LOS-27. Medical Care Research and Review, 69(4), 432-459.

Taylor Newberry Consulting (2018). Organizational Learning Self-Assessment Tool V1.0. Erişim adresi https://theonn.ca/wp-content/uploads/2018/05/SelfAssessment-Tool-DRAFT.pdf

Tolgay, F. (2010). Öğrenen Organizasyonlar ve Bir Uygulama. İstanbul: Bahçeşehir Üniversitesi, Sosyal Bilimler Enstitüsü.

Williams, A.P.O. (1980). Integrating Individual and Organisational Learning: A Model and Case Study. Management Education and Development, 1980(11), 7-20.

Willis, V.J. (2001). 'Shared Vision'; Are We At Risk Of Creating Monochromatic Organizations. Academy of Human Resource Development 2001 Conference, 2, 880-887.

Yaşlıoğlu, M.M., Şap, Ö., ve Toplu, D. (2014). An Investigation of the Characteristics of Learning Organizations in Turkish Companies; Scale Validation. Procedia Social and Behavioral Science, 2014(150), 726-734.

Yorks, L., O'Neil J. ve Marsick V.J. (1999). Action Learning; Theoretical Bases and Varieties of Practice. Advances in Developing Human Resources, 1(2), 1-18.

Yücel, İ. (2007). Öğrenen Örgütler ve Örgüt Kültürü -Bir Uygulama-, Yüksek Lisans Tezi, Erzurum: Atatürk Üniversitesi, Sosyal Bilimler Enstitüsü. 